\title{
A new distributional record of Ficus altissima Blume (Moraceae) in Tripura: an occasionally confused fig species with Ficus benghalensis $\mathbf{L}$.
}

\author{
Smita Debbarma, Biplab Banik*, Koushik Majumdar \& Badal Kumar Datta \\ Plant Taxonomy and Biodiversity Laboratory, Department of Botany, Tripura University, Suryamaninagar 799 022, Tripura, India \\ *Email: biplab.botany@tripurauniv.in
}

\section{ARTICLE HISTORY}

Received: 06 August 2020

Accepted: 15 October 2020

Published: 28 October 2020

\section{KEYWORDS}

Fig

Frugivores

Keystone species

\section{ABSTRACT}

The present communication is the first report of new distributional record of Ficus altissima Blume (Moraceae) in Tripura. F. altissima was found to be an important feeding and nesting habitat for forest frugivores, since the genus is very rich in diversity and is considered as a keystone species. This also possesses huge scope to understand the mechanism of interactions especially for conservation of rich avifaunal diversity. Brief description and field photographs are presented for facilitating easy identification of the species.

\section{Introduction}

Ficus L. is one of the largest genus of angiosperm with about 850 species comprising trees, shrubs, climbers, and creepers distributed throughout tropics and subtropical regions (1-3). The species of Ficus are instantaneously recognizable by the very distinguishing inflorescence, the "syconium". Fig wasps, Hymenoptera of the family Agaonidae, are exceptionally specialized symbiotic pollinators of Ficus with life cycles closely tied to the flowering and fruiting cycles of the figs. Fig trees are being keystone species and ecologically significant because they sustain populations of the many seed dispersing animals that feed on their fruits throughout the year (4).

In India, the genus is represented by about 115 taxa, of which 89 species and 26 infraspecific taxa with high species richness in the North East India (5). The first systematic account on Indian Ficus was prepared and published by King (6-7). He had recorded 112 species and 47 infraspecific taxa from whole British India (7), out of which only 75 species and 16 infraspecific taxa were reported from the present geographical boundary of India (5). A great number of works had been published on the systematics of Ficus from different regions of the world (2, 8-10) which have contributed to identification, classification and nomenclature. The genus has been further classified into six subgenera, 19 sections and 27 subsections based on morphological characters and distribution pattern (2).

Ficus benghalensis L. (=F. indica L.) is believed to be the giant species of Ficus in India and some of its morphological characters are overlaping with $F$. altissima. As per the description (11), the main differences between $F$. altissima and $F$. benghalensis, two tall banyans with somewhat similar leaves and syconium is that, $F$. benghalensis has a much more widely spreading crown than that of $F$. altissima and infinitely more secondary trunks. Both the species commonly have two sets of large basal veins. The ripe figs of $F$. benghalensis are globose, red, velvety, smaller than those of $F$. altissima, and have three separate leafy basal bracts. F. altissima has glossy leaves with a conspicuous light-coloured V shaped by its single set of large basal veins, and a rounded apex bearing all abrupt acumen. The figs of $F$. altissima are ovoid, usually yellow and bare, and rest on a thick pad of united basal bracts.

The state of Tripura situated in the sub-Himalayan region of North East India. Indo-Burma biodiversity region is considered as one of the hotspots in the world and the state of Tripura is being part of it (12-13). According to the Bio-geographic classification of India, the

(C) Debbarma et al (2020). This is an open-access article distributed under the terms of the Creative Commons Attribution License, which permits unrestricted use, distribution and reproduction in any medium, provided the original author and source are credited (https://creativecommons.org/licenses/by/4.0/).

To cite this article: Debbarma S, Banik B, Majumdar K, Datta B K. A new distributional record of Ficus altissima Blume (Moraceae) in Tripura: an occasionally confused fig species with Ficus benghalensis L Plant Science Today. 2020;7(4):658-662. https://doi.org/10.14719/pst.2020.7.4.896 
state is in the "North-East" bio-geographic zone (14) and has a geographical area of $10,491 \mathrm{~km}^{2}$. As per the report of the Forest Survey of India (15) total forest and tree cover in the state is $8,044 \mathrm{~km}^{2}$ i.e., $76.71 \%$ of the total State's geographical area. In the North-eastern states of India, F. altissima is reported from Arunachal Pradesh, Assam, Mizoram, Meghalaya and Sikkim (5). An early study by Deb (16) reported 22 species of Ficus from Tripura and there is no literature record for the occurrence of this species in the state of Tripura so far. Moreover, habitat assessment and floristic study of this genus in Tripura are scanty and still lacking. Consequently, the floristic study led to the collection and identification of $F$. altissima from Tripura and presented it as a new distribution record.

\section{Materials and Methods}

During the floristic survey in 2019 in the state of Tripura, we recorded a total of 8 Fig trees, four from Agartala with an average girth of $87 \mathrm{~cm}$, and three from Mandai with an average girth of $178 \mathrm{~cm}$, one from Tripura University Campus with girth of $206 \mathrm{~cm}$. The height of these trees ranged between 5-12 m. Specimens were collected from the field for taxonomical study and made into herbarium following the standard procedure (17). Critical examination of the specimens and detailed literature search $(11,18-20)$ confirmed its identity as Ficus altissima. This taxon is presented by a detailed description, details of phenology and distribution, IUCN status and field photographs (Fig. 1). The voucher specimens were deposited in the herbarium of the Department of Botany, Tripura University (TUH). A comparative account of major morphological characters of $F$. altissima and $F$. benghalensis is presented in Table 1.

\section{Results}

\section{Taxonomic treatment}

Ficus altissima Blume, Bijdr. Fl. Ned. Ind. 9: 444. 1825; King, Ann. Roy. Bot. Gard. (Calcutta) 1: 30, t.30, 31, 82s, 82s.1. 1887 \& in Hook. f., Fl. Brit. India 5: 504. 1888; Prain, Bengal Pl. 2: 734. 1903; Brandis, Indian Trees 600. 1906; Kanjilal et al., Fl, Assam 4: 240. 1940; Grierson \& Long, Fl. Bhutan 1(1): 97. 1983; Balakrishnan Flora of Jowai 2: 437. 1983; Haridasan \& Rao, F. Fl. Megh 2: 820. 1987; Chauhan in Hajra, Contrib. Fl. Namdapha 284. 1996; Bose et al., Trees of the world 1: 211. 1998; Wu et al., in Wu et al., Flora of China 5: 41. 2003; Berg and Corner in Nooteboom, Fl. Malesiana 17(2): 625. 2005; Giri et al., Mater. Fl. Arunachal Pradesh 2: 399. 2008; Berg et al., in Santisuk et al., Fl. of Thailand 10(4): 601. 2011; Chaudhary et al., Taiwania 57(2): 210. 2012.

F.laccifera Roxb., Fl. Ind. 3: 545. 1832; Wight, Icon. Pl. Ind. Orient. 2: t. 656. 1843.

F. altissima var. laccifera (Roxb.) Prain. in Bengal Pl. 2: 734. 1903.

Urostigma lacciferum (Roxb.) Miq. in London J. Bot. 6: 575. 1847.

Urostigma altissimum (Blume) Miq. in H. Zollinger, Syst. Verz. Ind. Archip. 2: 90. 1854.
Spreading tree, 25-30 m tall. Bark light greenish gray smooth. Branchlets green, ca. $1 \mathrm{~cm}$ thick, pubescent; scars of leaves and figs prominent. Stipules $1.7-7.0 \mathrm{~cm}$ long thick, leathery with grey silky hairs. Petiole 2-5 cm long; lamina deep green, broadly ovate to broadly ovate-elliptic, 16-20 × 10-12 cm, thick, leathery, glabrous, broadly cuneate at base, entire at margin, apex acute; midrib prominent; secondary veins 6-12 pairs, reticulate venation clearly defined in dry leaf. Figs axillary on leafy branchlets, paired, sessile, ellipsoid-ovoid, 2-3 × 1.5-2.0 cm, light green, white dotted, pubescent when young, apical pore navel-like, concave, reddish orange when mature; involucral bracts hoodlike, covering young fig, caducous, apex broadly obtuse, scar ringlike. Male, gall and female flowers within same fig. Male flowers: scattered; perianth lobes 4, transparent; stamen 1. Gall flowers: perianth lobes 4; style subapical, long. Female flowers: sessile; perianth lobes; style elongated. Achenes tuberculate.

Specimen examined: India, Tripura, West Tripura District, Agartala, $\pm 14 \mathrm{~m}, 2^{\circ} 49^{\prime} 52.2^{\prime \prime}, 91^{\circ} 17^{\prime} 09.7^{\prime \prime}$; Mandai, $\pm 72 \mathrm{~m}, \quad 23^{\circ} 51^{\prime} 39.4^{\prime \prime}, 91^{\circ} 28^{\prime} 46.7^{\prime \prime}$; Tripura University Campus, $\pm 18 \mathrm{~m}, 23^{\circ} 45^{\prime} 41.7^{\prime \prime}, 91^{\circ} 15^{\prime} 54.8^{\prime \prime}$; Datta and Debbarma 2748 (TUH) (Fig. 2).

Distribution: India (Andaman \& Nicobar Islands, Arunachal Pradesh, Assam, Deccan Peninsular region, Meghalaya, Mizoram, Sikkim, Tripura and West Bengal), Bangladesh, Bhutan, China, Indonesia, Malaysia, Myanmar, Nepal, Philippines, Sri Lanka, Thailand, Vietnam.

\section{Flowering and Fruiting: Flowering - March to April; Fruiting - May to July.}

IUCN Red List status: Least concern, ver. 3.1. (21).

\section{Discussion}

The identification of specimen was determined by a critical examination and turned out it as a new distributional record for the "flora of Tripura". The state of Tripura possesses special significance in the biogeography of the North-eastern region because of its unique location and habitat heterogeneity. Since the state Tripura, the third smallest state of Northeast India holds rich floristic diversity in wide range of vegetation types along with their varied composition and structure, environmental factors such as humidity, temperature and rainfall. Ficus forms a unique group within the subset of plants with bird eaten fruit because of their numerical abundance, intra-crown synchrony of fruit ripening, relatively short intervals between fruiting, large crop sizes and intrapopulation fruiting asynchrony. Fig trees often survive in human-dominated landscapes because of their cultural significance. It was found that $F$. benghalensis, $F$. religiosa and $F$. altissima have considerable religious associations in Hinduism and Buddhism, and these cultural factors contribute to the safeguarding of mature trees. However, with agricultural intensification, people cut down trees when they interfered with their daily activities. Extensive conversion of forests for cash crop plantation in this region has resulted in the emergence of landscape tracts that are a heterogeneous mixture of agriculture, humansettlement and forest fragments. 


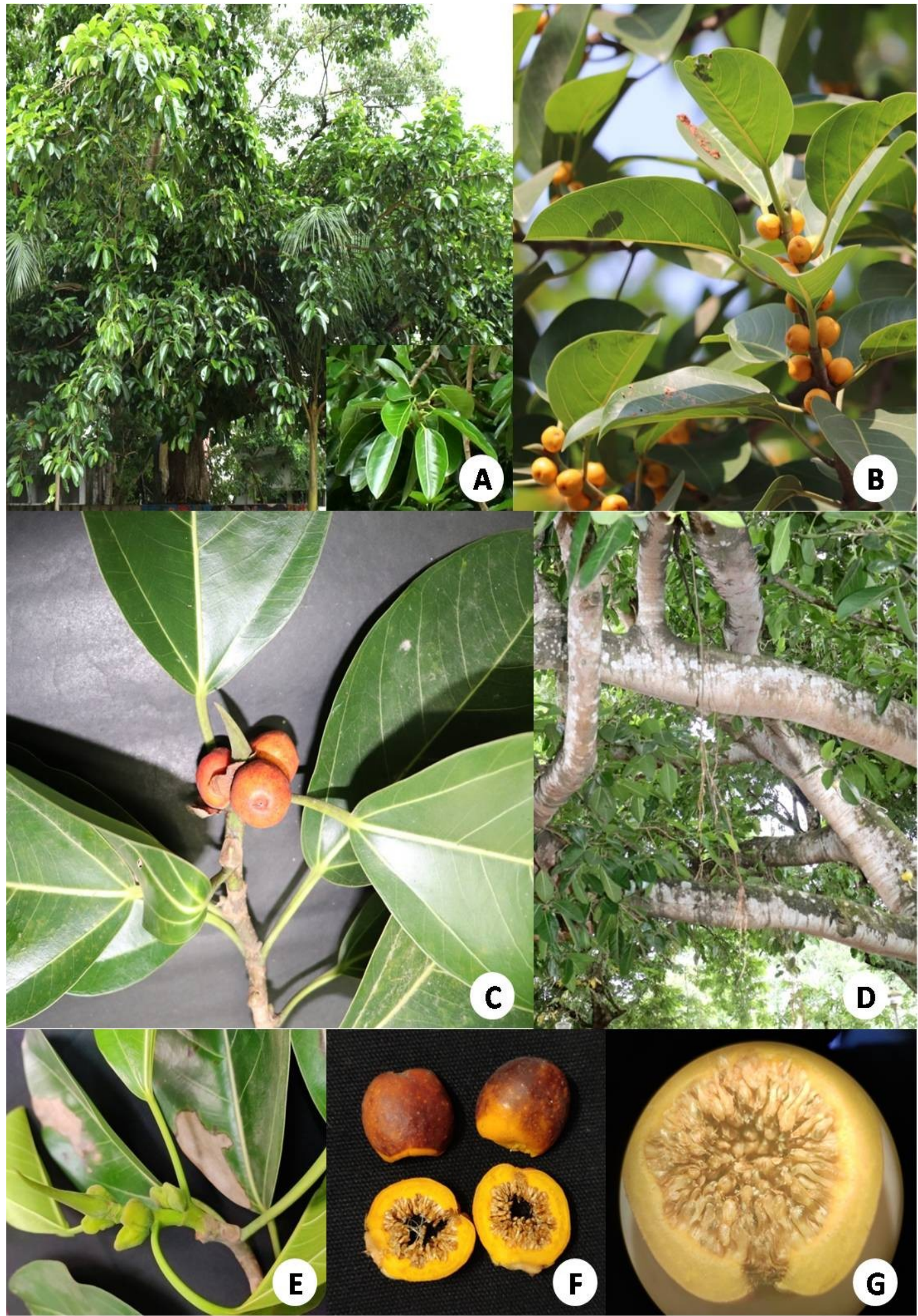

Fig. 1. Ficus altissima Blume. A. Habit. B. Twig with figs. C. Mature figs. D. Trunk and branching. E. Immature figs covered by calyptra. F. Mature syconia (l.s.). G. Microscopic view of syconium (l.s.) 
Table 1. Comparison of major morphological characters of $F$. altissima and $F$. benghalensis.

\begin{tabular}{|c|c|c|}
\hline Characters & Ficus altissima & Ficus benghalensis \\
\hline Leaves & $16-20 \times 10-12 \mathrm{~cm}$, secondary veins $6-12$ pairs & $10-17 \times 5-12 \mathrm{~cm}$; secondary veins $4-8$ pairs \\
\hline Stipules & $\begin{array}{l}\text { Linear-lanceolate, greenish- cream in colour; } 1.7- \\
7.0 \mathrm{~cm} \text { long }\end{array}$ & Triangular, cream in colour; $1.0-4.0 \mathrm{~cm}$ long \\
\hline Syconium & $\begin{array}{l}\text { Ellipsoid to sub-globose, } 2-3 \times 1.5-2.0 \mathrm{~cm} \text {; white } \\
\text { dots present; bright red at maturity }\end{array}$ & $\begin{array}{l}\text { Depressed globular, } 1.0-1.7 \times 1.4-2.2 \mathrm{~cm} \text {; short white } \\
\text { hairs present; crimson red at maturity }\end{array}$ \\
\hline Ostiole & Naval shape or concave & Convex \\
\hline
\end{tabular}

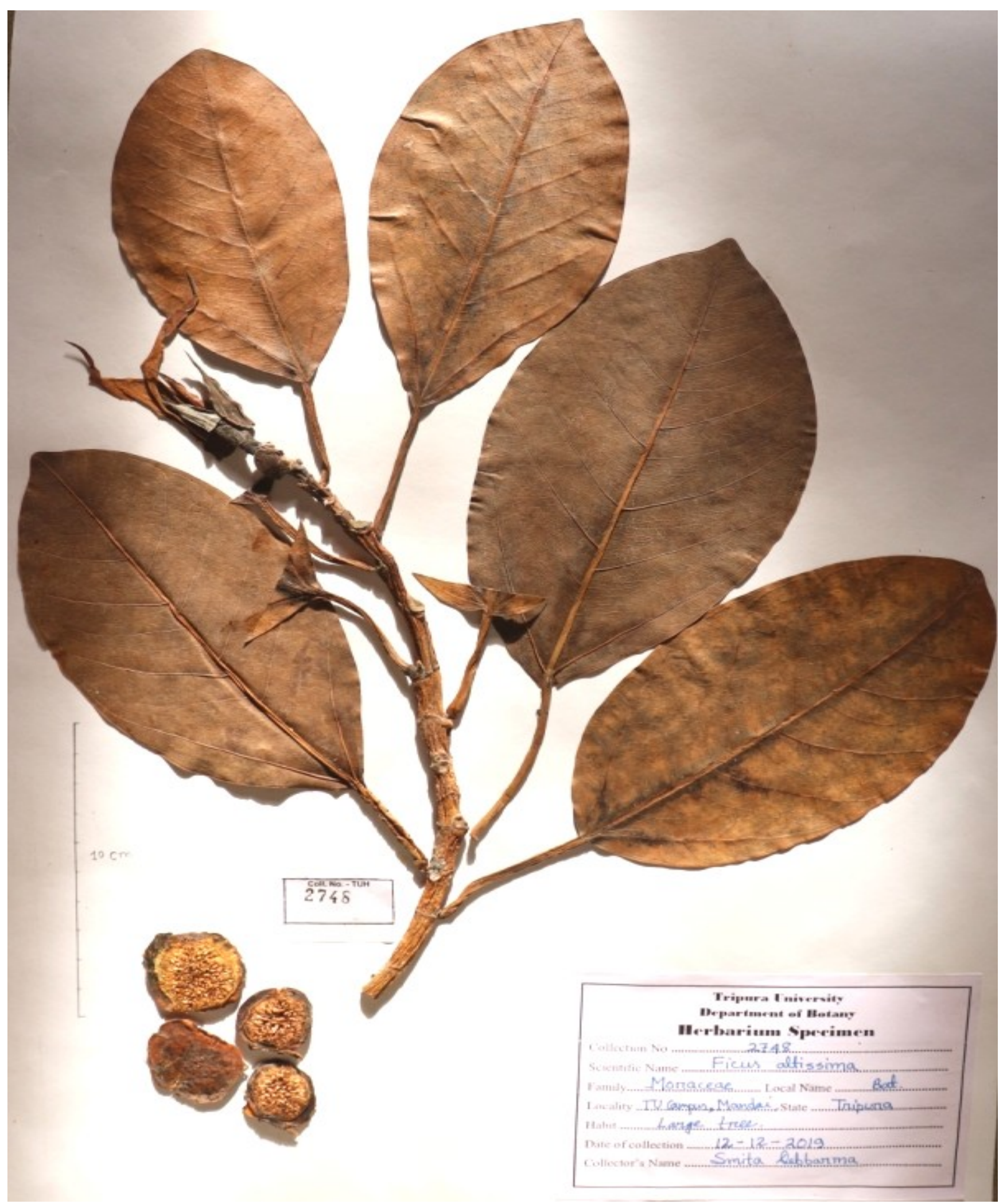

Fig. 2. Herbarium sheet of Ficus altissima Blume 


\section{Acknowledgements}

The authors are thankful to the Head, Department of Botany, Tripura University for providing laboratory facilities.

\section{Authors' contributions}

SD and BB carried out field visits, collections, identifications, and initial drafting of the manuscript. $\mathrm{KM}$ and $\mathrm{BB}$ analysed and finalised the manuscript for publication. The whole work was revised and supervised by BKD.

\section{Conflict of interests}

The authors don't have any competing interests.

\section{References}

1. Frodin DG. History and concepts of big plant Genera. Taxon. 2004;53(3):753-76. https://doi.org/10.2307/4135449

2. Berg CC, Corner EJH. Moraceae (Ficus). In: HP Nooteboom, editor. Flora Malesiana, National Herbarium of the Netherlands. Leiden: 2005;17(2):p.1-730.

3. Rønsted N, Weiblen GD, Clement WL, Zerega NJC, Savolainen V. Reconstructing the phylogeny of figs (Ficus, Moraceae) to reveal the history of the fig pollination mutualism. Symbiosis. 2008;45(1):45-55.

4. Shanahan M, SO S, Compton SG, Corlett R. Fig-eating by vertebrate frugivores: A global review. Biol. Rev. Camb. Philos. Soc. https://doi.org/10.1017/S1464793101005760 2001;76:529-72

5. Chaudhary LB, Sudhakar JV, Kumar A, Bajpai O, Tiwari R, Murthy GVS. Synopsis of the genus Ficus L. (Moraceae) in India. Taiwania. 2012;57(2):193-216 https://doi.org/10.6165/tai.2012.57(2).193

6. King G. The Species of Ficus of the Indo - Malayan and Chinese Countries. Ann. Roy. Bot. Gar., Calcutta, 1887-1888;1:1-185.
7. King G. Ficus L. In: Hooker, J. D., The Flora of British India. L. Reeve and Co., London, UK,1888;5:494-37.

8. Corner EJH. Check list of Ficus in Asia and Australasia with keys to identification. Gardens’ Bulletin Singapore. 1965;21:1186.

9. Berg CC. Classification and distribution of Ficus. Experientia. 1989;45:605-11.

10. Dixon DJ. A taxonomic revision of the Australian Ficus species in the section Malvanthera (Ficus subg. Urostigma: Moraceae) Telopea. 2003;10:125-53. https://doi.org/10.7751/telopea20035611

11. Barrett MF. Ficus altissima. Bulletin of the Torrey Botanical Club, 1945;72(4):394-98.

12. Myers N, Mittermier RA, Mittermier CG, Fonseca da, GAB, Kent J. Biodiversity hotspots for conservation priorities. Nature. 2000; 40:853-58. http://dx.doi.org/10.1038/35002501

13. Mao AA, Hynniewta TM, Sanjappa M. Plant Wealth of Northeast India with Reference to Ethnobotany. Indian Journal of Traditional Knowledge. 2009;8:96-103.

14. Champion HG, Seth SK. A Revised Survey of the Forest Types of India, Natraj Publishers, Dehradun, India. 1968;p.404.

15. FSI. India State of Forest Report. Forest Survey of India, Ministry of Environment and Forests, Dehradun, 2015.

16. Deb DB. The Flora of Tipura State. Todays \& Tomorrow's Printers \& Publishers, New Delhi, 1981:2;p.210-20.

17. Jain SK, Rao RR. A Handbook of Field and Herbarium Methods, Today and Tomorrows' Printers and Publishers, New Delhi, 1977.

18. Hooker JD. The Flora of British India. L. Reeve \& Co., London, 1890; 5; p.910.

19. Kanjilal UN, Kanjilal PC, De R, Das AK. Flora of Assam. Vol-4. Govt. Press, Shillong, 1940; p. 232-66.

20. Haridasan K, Rao RR. Forest Flora of Meghalaya. Bishen Singh Mahandra Pal Singh. Dehradun, 1987;2:p.816-35.

21. Shao Q, Zhao L. Botanic Gardens Conservation International (BGCI) \& IUCN SSC Global Tree Specialist Group. Ficus altissima. The IUCN Red List of Threatened Species; 2019: e.T147483545A147650743. https://dx.doi.org/10.2305/IUCN.UK.2019 2.RLTS.T147483545A147650743.en. [cited 2020 Oct 2]. Available from: http://www.iucnredlist.org 